\title{
Marketing margins of aquaculture shrimp production in Kedah
}

\author{
Wen Chiat Lee'*, Siak Ze Lim², K. Kuperan Viswanathan ${ }^{3}$ and Md Ariful Islam² \\ ${ }^{1}$ Faculty of Business Management, Universiti Teknologi MARA, Cawangan Sarawak, Malaysia \\ 2 Department of Economics and Agribusiness, School of Economics, Finance and Banking, Universiti Utara \\ Malaysia, 06010 Sintok, Kedah Darul Aman, Malaysia. \\ ${ }^{2}$ Othman Yeop Abdullah Graduate School of Business, Universiti Utara Malaysia, 06010 Sintok, Kedah Darul Aman, \\ Malaysia.
}

*Corresponding author: wenchiat@uitm.edu.my

\begin{abstract}
Shrimp aquaculture has great potential for providing income and employment opportunities to farmers. Shrimp production can also contribute to economic growth given its high value and demand in Malaysia. However, it is often said that players in the marketing channel extract high margins for themselves. This study intends to verify this claim by examining a case study based on white leg shrimp (Litopenaeus vannamei) aquaculture in Kedah. The data for this study was obtained from a detailed study involving a shrimp retailer in Kedah. The marketing margins were calculated from the interviews of the farmer and the retailer. The results showed that the marketing channel was quite efficient because there was no large gap in the prices between the marketing channels. The difference between retail price and farm price is only RM7 per kilogram for the white shrimp which accounts for 43.75 percent of total farm price and represents the cost of bringing shrimps from the farm to the retail market.
\end{abstract}

Keywords: Shrimp production, Supply chain, Marketing margins, Marketing channel, White shrimp

\section{Introduction}

Shrimp production is an important activity in Malaysia as it provides employment opportunities and contributes to economic growth. Moreover, shrimp farming is also a source of foreign exchange. Shrimp production is divided into the amount landed by capture fisheries and that produced by aquaculture. Aquaculture of shrimp is gaining more interest as the harvest from the capture fisheries decline due to overharvesting and pollution concerns increase (Ismail and Abdullah, 2013). Third National Agriculture Policy of included a number of initiatives for promoting brackish water shrimp culture (Ministry of Agriculture Malaysia, 2003). However, despite its enormous potential and importance, the shrimp aquaculture continues to face some challenges

Marketing is among the issues constraining affordable and sustainable supply of shrimp to the consumers. This has been linked to players in the supply chain seeking to increase their profit margin (Chowdhury et al., 2013). This study was undertaken to unearth the facts surrounding this prevailing perception in Kedah.

\section{Status of shrimp farming in Malaysia}

Malaysia has a long coastline of 4,809 $\mathrm{km}$ in length and the $329,750 \mathrm{~km}^{2}$ of land area in Peninsular Malaysia consists of 2,031 km coastline while Sabah and Sarawak (East Malaysia) has a coastline of $2,778 \mathrm{~km}$. In Malaysia, the the total area for shrimp farming is estimated at 5,100 hectares (Chowdhury, et al., 2013). In the year 2017, brackishwater aquaculture production in Malaysia was 324,300 tonnes whereas freshwater aquaculture production was 102,500 tonnes (Malaysian Department of Fisheries, 2017). Shrimp shared a major part of the brackishwater aquaculture.

Aquaculture production in the country is divided into freshwater culture and brackish water culture. In 2017, the retail value freshwater aquaculture production was RM1.08 billion whereas retail value for aquaculture production in brackishwater culture system was RM2.82 billion (Department of Fisheries Malaysia, 2017) The number of people involved in aquaculture was 31,637 (Department of Fisheries, 2017). The brackishwater culture system contributed about 72.31 percent to total aquaculture production in 2017 (Department of Fisheries Malaysia, 2017). The bulk of brackishwater culture production in Malaysia consisted of Tiger prawns (Penaeus monodon) and white leg prawns (Litopenaeus vannamei). These two species accounted for 45.48 percent of total retail value of brackishwater culture production in Malaysia (Malaysian Department of Fisheries, 2017). The Malaysian shrimp export value in 2017 was RM690 million from 24,867 tonnes of production (Reference??). Major shrimp importing countries were China, Canada, US, Japan (Harkell, 2018). Production figures for the two species are given in Table 1. 
Table 1. Aquaculture production of tiger shrimps and white leg shrimps in Malaysia

\begin{tabular}{llcc}
\hline Year & Tonnes & $\begin{array}{c}\text { Wholesale } \\
\text { Value } \\
\text { (RM'000) }\end{array}$ & $\begin{array}{c}\text { Retail } \\
\text { Value } \\
\text { (RM'000) }\end{array}$ \\
\hline 2010 & 87202.61 & 1178964.59 & 1491253.25 \\
2011 & 67472.80 & 888600.33 & 1115406.96 \\
2012 & 55569.06 & 755549.73 & 992600.44 \\
2013 & 49956.92 & 828027.51 & 975347.04 \\
2014 & 61386.35 & 1252309.62 & 1466627.70 \\
2015 & 52570.49 & 1140956.74 & 1327516.13 \\
2016 & 43247.54 & 918024.80 & 1155529.53 \\
2017 & 45780.96 & 1067124.45 & 1284116.31 \\
\hline
\end{tabular}

Source: Department of Fisheries Malaysia (2010; 2011; 2012;

2013; 2014; 2015; 2016; 2017)

It is evident from the data in Table 1 that the aquaculture production of tiger shrimp and white leg shrimp in Malaysia had declined from 87202.61 tonnes in 2010 to 45780.96 tonnes in 2017, amounting to a reduction of 47.50 percent. This is due to the outbreak of diseasesand a fall in the market price in recent years (Chowdhury, Talib \& Yahya, 2013). The wholesale and retail value of shrimp aquaculture production f fell from RM1.17 billion in 2010 to RM1.067 billion in 2017 and from RM1.49 billion in 2010 to RM1.28 billion in 2017, respectively. In this study, the focus is on the white leg shrimp. Its l production was 1,813 tonnes in 2017 compared to that of farmed tiger shrimp (25 tonnes in 2017) (Department of Fisheries, 2017).

\section{Shrimp aquaculture in Kedah}

Aquaculture is popular in Kedah. Kedah is the seventh largest aquaculture producer in Malaysia (Department of Fisheries Malaysia, 2018). While the total area of freshwater culture is 9294 square meters compared to 136,455 square meters for brackish water culture, a major part is for shrimp farming.

There are about 600 people involved in aquaculture in Kedah (Department of Fisheries Malaysia, 2018). Of these, 241 work in the are brackish farming whereas 359 carry out freshwater aquaculture. Kedah produces 2,793 tonnes of white leg shrimp which is about 8 percent of the total production of this species in Malaysia. and 96 tonnes of cultured tiger shrimps in the year 2018 (Check production data, provide correct figures with reference). Kedah is the fifth largest white leg shrimp producing state in Malaysia after Sabah (12,937.40 tonnes), Johor (5,748.67 tonnes), Pahang (4,275.14 tonnes), Sarawak (3449.74 tonnes) (Department of Fisheries Malaysia, 2018).
Most low-income households receive assistance in terms of cash or pond facilities to start their aquaculture business. Training and extension services are also provided to increase their technical knowledge and skills in aquaculture. Currently, Kedah's aquaculture sub-sector is one of the most successful development programs in the Northern Corridor Economic Region Project (NCER), yielding an average annual growth rate up to 36 percent for the period 1997-2013 (Department of Fisheries Malaysia, 2010; $2011 ; 2012$; 2013; 2014; 2015; 2016; 2017).

\section{Methodology}

The data for this study was retrieved from a comprehensive case study of a shrimp aquaculture enterprise and a shrimp retailer in Semeling, Kedah. Two sets of questionnaires were used to interview the shrimp farmers and retailers in Semeling. For the farmers, the questions covered the cost of capital, pond price, labour cost per month, shrimp feed, production per pond, and price per kilogram of white leg shrimp. The shrimp retailer were asked about the market price of shrimp and the amount marketed daily.

\section{Production cost of shrimp in Kedah}

The cost of production for white leg shrimp farming is divided into capital cost (fixed costs) and operating cost (variable costs). The capital cost of the current case study is shown in Table 2 whereas the operating cost is shown in Table 3.

Table 2. Capital cost per pond for white leg shrimp production in Kedah

\begin{tabular}{|c|c|c|c|}
\hline No. & Item & Quantity & $\begin{array}{l}\text { Cost } \\
\text { (RM) }\end{array}$ \\
\hline 1 & Land & $\begin{array}{c}0.50 \\
\text { Hectare }\end{array}$ & 30,000 \\
\hline 2 & Pond construction & $\begin{array}{c}0.50 \\
\text { Hectare }\end{array}$ & 20,000 \\
\hline 3 & $\begin{array}{l}\text { Machinery } \\
\text { (10 inch water pump) }\end{array}$ & 1 & 10,000 \\
\hline 4 & $\begin{array}{l}\text { Machinery } \\
\text { (Water Aerator) }\end{array}$ & 6 & 3,000 \\
\hline 5 & $\begin{array}{l}\text { Machinery } \\
\text { (3 Phase Induction Motor) }\end{array}$ & 4 & 4,800 \\
\hline 6 & $\begin{array}{l}\text { Machinery } \\
\text { (Auto Feeder) }\end{array}$ & 1 & 2,500 \\
\hline 7 & Electricity Supply System & 1 & 4,000 \\
\hline & Total Cost & & RM74,300 \\
\hline
\end{tabular}

Source: Current Case Study (2018) 
From Table 2, the largest component or about 40 percent of the cost is for land while 27 percent is for pond construction. These two components alone account for some 70 percent of the total capital costs for white leg shrimp production. Machinery and electricity account for some 30 percent of the total capital cost.

Table 3. Operating costs per pond for white leg shrimp production in Kedah

\begin{tabular}{|c|c|c|c|}
\hline No. & Items & Quantity & $\begin{array}{l}\text { Cost } \\
(\mathrm{RM})\end{array}$ \\
\hline 1 & Fingerlings & 700,000 & 14,000 \\
\hline 2 & Labour Cost & 3 months & 2,600 \\
\hline 3 & Vitamin C Purchase & 75 kilogram & 6,750 \\
\hline 4 & $\begin{array}{l}\text { Cost of machine } \\
\text { maintenance }\end{array}$ & 3 times per cycle & 1,500 \\
\hline 5 & $\begin{array}{l}\text { Cost of water pump } \\
\text { maintenance }\end{array}$ & 1 time & 950 \\
\hline 6 & Electricity costs & 3 months & 9,000 \\
\hline 7 & Feeding cost & 3 months & 40,000 \\
\hline 8 & $\begin{array}{l}\text { Bacteria treatment } \\
\text { cost }\end{array}$ & 3 months & 6,750 \\
\hline 9 & $\begin{array}{l}\text { Effective } \\
\text { microorganism } \\
\text { purchase }\end{array}$ & 30 litres & 660 \\
\hline 10 & Cold gray powder & 1 tonne & 120 \\
\hline 11 & Hot gray powder & 3 tonnes & 960 \\
\hline \multirow[t]{2}{*}{12} & $\begin{array}{l}\text { White medicine } \\
\text { (if needed) }\end{array}$ & 8 kilograms & 450 \\
\hline & Total Cost & & 83,740 \\
\hline
\end{tabular}

Source: Current Case Study (2018).

Evidently, the feed costs account for about 48 percent of the total operating costs. The other major component of the operating cost is the cost of fingerlings accounting for about 17 percent of the total operation costs. Thus, feed and fingerling costs are the most important in managing the cost of culture of the white leg shrimp. Each fingerling costs RM0.02 and feeding it continues for three months before harvesting takes place A nutritional feed is expensive. It contains fish meal, broken rice, rice bran, soybean meals, vitamins and minerals to meet the nutritional requirements of the shrimp. A cheap feed that does not contain the required amounts of the needed nutrients cannot support the survival and growth of the shrimp through the production cycle.

\section{Sales and farm prices of white leg shrimp in Kedah}

The prices for whiteleg shrimp harvested per cycle are shown in Table 4. The price for white leg shrimp is based on one pond in one farm in Kedah. One cycle covers the time from stocking of the fingerlings to the final harvest. One cycle takes about 90 days to completee consists of five harvests.

Table 4. Lists of farm prices for white- leg shrimps for each harvest in one cycle

\begin{tabular}{|c|c|c|}
\hline $\begin{array}{l}\text { Times of } \\
\text { Harvest }\end{array}$ & $\begin{array}{l}\text { Quantity } \\
\text { (kilograms) }\end{array}$ & $\begin{array}{l}\text { Price (RM) } \\
\text { per kilogram }\end{array}$ \\
\hline
\end{tabular}

\begin{tabular}{cccc}
\hline 1 & 1100 & $16(100$ tails $)$ & 17,600 \\
2 & 1200 & $17(80$ tails $)$ & 20,400 \\
3 & 1100 & $19(60$ tails $)$ & 20,900 \\
4 & 1200 & $22(50$ tails $)$ & 26,400 \\
5 & 1100 & $25(40$ tails $)$ & 27,500 \\
Total & 5500 & & 112,800 \\
\hline
\end{tabular}

The total weight of harvested white shrimp for one cycle (90 days/ three months) is 5.5 tonnes or 5500 kilograms. There are five different harvests in one cycle. The objective of having five different harvests is to avoid competition among the shrimp and to provide more space for the small shrimps to grow into bigger shrimp.

The prices are also different according to the size of the shrimp. e Bigger shrimp fetches higher prices. The total revenue from the saleof white shrimp was RM112800.

The profit for one shrimp farmer after one cycle was RM29,060. This was calculated from total sales revenue for one cycle (RM112,800) minus total operating cost for that cycle (RM83,740). The capital cost is not taken into account for the calculation of profit because itis fixed cost. 


\section{Marketing channel and price for each player}

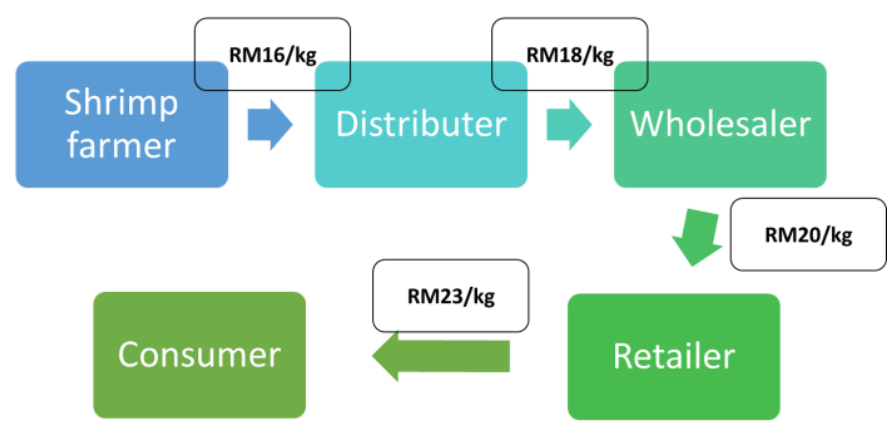

Figure 1. Marketing channel for white shrimp farmed in Kedah

Figure 1 shows the marketing channel for white shrimp farming in Kedah. It comprises five players; shrimp farmer, distributor, wholesaler, retailer and consumer. The shrimp farmer sells the shrimps at RM16 per kilogram to the distributor then the distributor sells RM18 per kilogram to the wholesaler. The wholesale price for white shrimp is RM20 per kilogram whereas the retail price for white shrimp is RM23 per kilogram. The cost of marketing is RM7 per kilogram (an increase of 43.75 percent from farm price to retail price). The marketing channel is quite efficient because there is no big gap between the channels.

The retailer is selling an average of 25 kilogram per day and is making RM75 profit per day ((RM23-20 per kilogram) X 25 kilogram). Thus, a shrimp retailer would make RM1,875 per month (RM75 profit per day X 25 operating days). The earning of every player in the marketing channel for shrimp farming in Kedah is not exorbitant. Business players are earning quite normal profits and the marketing chain is not dominated or controlled by any single player.

\section{Conclusions}

This study outlined the marketing channel for whiteleg shrimp farming in Kedah. The marketing channel does not exhibit price exploitation by any single player. There is no large increase in the price from farm gate valuee to the retail price (only a price increase of 43.75 percent). The wholesaler earns RM2 per kilogram of shrimp whereas the retailer earns RM3 per kilogram. The profit margin of white shrimp is not exorbitant as every player in the marketing channel does not add on a high price from their preceding market chain price. The consumers at the retail level in Kedah are not paying a very high price for the shrimp considering the farm gate price.
The shrimp wholesalers and distributors should increase the quantities of shrimp sold to increase their earnings. They can make more money by selling more quantities and not depend on the price margin alone. The volume suggested would be at least 1000 kilograms for one wholesaler or distributor. Retailers often cannot handle bigger volumes because they are constrained by the lack of capital. From this study it is evident that a retailer can earn RM1,875 a month on an average by selling whiteleg prawn to the consumers.

\section{References}

Chowdury, M.A., Talib, A. \& Yahya, K. (2013). A Review on Marine Shrimp Aquaculture Production Trend and Sustainability in Malaysia and the World Perspective. Proceedings of the Conference: International Fisheries Symposium, Can Tho University, Can Tho, Vietnam.

Department of Fisheries Malaysia (2010). Annual Fisheries Statistics 2010. Kuala Lumpur: Ministry of Agriculture and Agro-Based Industry Malaysia.

Department of Fisheries Malaysia (2011). Annual Fisheries Statistics 2011. Kuala Lumpur: Ministry of Agriculture and Agro-Based Industry Malaysia.

Department of Fisheries Malaysia (2012). Annual Fisheries Statistics 2012. Kuala Lumpur: Ministry of Agriculture and Agro-Based Industry Malaysia.

Department of Fisheries Malaysia (2013). Annual Fisheries Statistics 2013. Kuala Lumpur: Ministry of Agriculture and Agro-Based Industry Malaysia.

Department of Fisheries Malaysia (2014). Annual Fisheries Statistics 2014. Kuala Lumpur: Ministry of Agriculture and Agro-Based Industry Malaysia.

Department of Fisheries Malaysia (2015). Annual Fisheries Statistics 2015. Kuala Lumpur: Ministry of Agriculture and Agro-Based Industry Malaysia.

Department of Fisheries Malaysia (2016). Annual Fisheries Statistics 2016. Kuala Lumpur: Ministry of Agriculture and Agro-Based Industry Malaysia.

Department of Fisheries Malaysia (2017). Annual Fisheries Statistics 2017. Kuala Lumpur: Ministry of Agriculture and Agro-Based Industry Malaysia.

Department of Fisheries Malaysia (2018). Annual Fisheries Statistics 2018. Kuala Lumpur: Ministry of Agriculture and Agro-Based Industry Malaysia

Harkell, L. (2018). China's black tiger shrimp buzz helps Malaysian exporters. Retrieved from https://www.undercurrentnews.com/ 2018/07/31/chinasblack-tiger-shrimp-buzz-helps-malaysian-exporters/

Ismail, M.M. \& Abdullah, A.M. (2013). Shrimp trade competitiveness of Malaysia and selected ASEAN countries. Journal of International Food and Agribusiness Marketing 25, 98-115.

Ministry of Agriculture Malaysia. (2003). Third National Agricultural Policy (1998-2010) - A summary. Putrajaya: Ministry of Agriculture Malaysia. 